\title{
PENINGKATAN KEMAMPUAN GURU MEMANFAATKAN IT DALAM PEMBUATAN PERANGKAT PEMBELAJARAN MELALUI IN HOUSE TRAINING ( IHT ) DI SD NEGERI 02 KUBANG
}

\author{
Hartati Wirda \\ Email: hartati.wirda@gmail.com
}

\begin{abstract}
This research is a School Action Research (PTS). The research was conducted at SDN 02 Kubang with the research subject was teachers who taught at SDN 02 Kubang in the second semester of the 2018/2019 academic year. There were 8 teachers as research subjects. Data were collected using observation sheets, observations of the principal's activities as researchers and teacher activities as research subjects and questionnaires. The research was conducted in 2 cycles, each cycle consisting of 3 meetings. The research findings obtained an increase of 15.48 points on the indicator of teacher observation sheets and 5 points on increasing the ability of teachers to use IT in arranging learning tools. From the questionnaire given to teachers, IHT also has a positive impact on teacher learning in class. So it can be concluded that IHT can improve the ability of teachers to use IT in making learning devices at SDN 02 Kubang semester 2 of the 2018/2019 academic year.
\end{abstract}

Keywords: Teachers' Ability, Utilization of IT, In House Training (IHT)

\begin{abstract}
Abstrak
Penelitian ini adalah Penelitian Tindakan Sekolah (PTS). Penelitian dilaksanakan di SDN 02 Kubang dengan subyek penelitian adalah guru-guru yang mengajar di SDN 02 Kubang pada semester 2 tahun pelajaran 2018/2019. Ada 8 orang guru sebagai subyek penelitian. Data dikumpulkan dengan menggunakan lembar observasi, observasi kegiatan kepala sekolah sebagai peneliti dan kegiatan guru sebagai subyek penelitian dan quesioner. Penelitian dilaksanakan dalam 2 siklus masing-masing siklus terdiri dari 3 pertemuan. Temuan penelitian diperoleh peningkatan 15,48 poin pada indikator lembar observasi guru dan 5 poin pada peningkatan kemampuan guru memanfaatkan IT menyusun perangkat pembelajaran. Dari quesioner yang diberikan kepada guru, IHT juga berdampak positif terhadap pembelajaran guru dikelas. Maka dapat disimpulkan bahwa IHT dapat meningkatkan kemampuan guru memanfaatkan IT dalam pembuatan perangkat pembelajaran di SDN 02 Kubang semester 2 tahun pelajaran 2018/2019.
\end{abstract}

Kata Kunci: Kemampuan Guru, Pemanfaatan IT, In House Training

\section{PENDAHULUAN}

Kepala Sekolah adalah guru yang diberi tugas tambahan untuk memimpin dan mengelola satuan pendidikan.Dalam upaya meningkatkan mutu pendidikan kepala sekolah dituntut untuk membina dan mengelola seluruh komponen sekolah: guru sebagai pendidik dan pengajar,tenaga administrasi sekolah, dan tenaga perpustakaan. 
Selanjutnya, Peraturan Menteri Pendidikan Nasional nomor 13 tahun 2007 tentang standar Kepala Sekolah/Madrasah menyatakan 5(lima) kompetensi yang harus dimiliki Kepala Sekolah, yaitu: Kompetensi Kepribadian, Manajerial, Kewirausahaan, Supervisi, dan Kompetensi Sosial. Teknik pelaksanaannya dijabarkan dalam Permendiknas nomor 28 tahun 2010 tentang Penugasan Guru sebagai Kepala Sekolah yang kemudian diganti dengan Permendikbud nomor 6 tahun 2018.

Peraturan Menteri Pendidikan dan Kebudayaan nomor 15 Tahun 2018 tentang Pemenuhan Beban Kerja Guru,Kepala Sekolah,dan Pengawas Sekolah menyatakan bahwa seorang Kepala Sekolah harus melaksanakan tugas pokok manajerial, pengembangan kewirausahaan,dan supervisi kepada guru dan tenaga kependidikan. Beban kerja Kepala Sekolah yang dimaksud bertujuan untuk mengembangkan sekolah dan meningkatkan mutu pendidikan. Dalam hal ini seorang Kepala Sekolah mampu membina guru-guru di sekolah menjadi guru yang aktif, kreatif, inovatif dalam pembelajaran.

Kompetensi profesional guru menurut Permendiknas nomor 35 tahun 2010 menuntut guru untuk mampu menguasai materi, serta informasi yang tepat dan mutakhir dalam RPP, melakukan evaluasi diri, mengaplikasikan PKB dalam menyusun administrasi pembelajaran,melakukan penelitian,dan memanfaatkan Information Technology (IT) dalam pembuatan perangkat pembelajaran.

Berdasarkan uraian di atas dapat disimpulkan bahwa kompetensi profesional dan indikatornya penguasaan materi, struktur konsep dan pola pikir keilmuan yang mendukung mata pelajaran yang diampu dan mengembangkan pembelajaran berbasis IT, membuat perangkat pembelajaran yang dibuat guru sebaiknya dikerjakan dengan teknologi komputerisasi. Administrasi yang dibuat dengan IT hasilnya akan lebih cepat, rapi, bagus, dan menarik.

Pelaksanaan kurikulum 2013 yang berbasis kompetensi lebih menekankan pada sains dan teknologi,sehingga dalam pelaksanaannya dibutuhkan usaha guru yang lebih ekstra.Guru harus mampu mengikuti siswa yang kompetitif,memiliki kemampuam berfikir tinggi dan tidak bersikap apatis terhadap siswa yang lemah dalam menyerap materi pelajaran.Begitu juga minat belajar siswa yang cukup beragam.Guru sebagai fasilitator harus mampu memilih metode,strategi,dan media pembelajaran yang dapat meningkatkan minat belajar peserta didik.Jadi apabila guru mampu menggunakan IT dalam pembuatan perangkat pembelajaran serta dapat memanfaatkan IT dalam proses pembelajaran,salah satu cerminan guru yang profesional.Guru yang profesional akan berdampak pada mutu pendidikan.

Disamping itu mutu pendidikan juga ditentukan oleh kualitas kepala sekolah,guru,ketersediaan buku,fasilitas belajar,dan dukungan orang tua dan masyarakat. Untuk meningkatkan kualitas guru dapat dilakukan dengan memberikan pelatihan-pelatihan pada kegiatan KKG atau di sekolah. Misalnya pelatihan menggunakan IT bagi guru yang belum mampu menggunakan IT.

Maka dari itu,guru yang profesional dituntut untuk mampu menggunakan IT dalam membuat perangkat pembelajaran serta memanfaatkan IT sebagai media pembelajaran.Memanfaatkan IT sebagai media pembelajaran merupakan hal yang sangat perlu. Benda yang jauh atau benda yang besar yang tidak mungkin dibawa langsung ke sekolah,dapat diamati siswa berupa gambar dengan menggunakan in fokus yang dihubungkan ke laptop. 
Berbeda halnya yang terjadi di Sekolah Dasar Negeri 02 Kubang Kecamatan Guguak Kabupaten Lima Puluh Kota.Guru yang mengajar di sekolah ini, belum seluruhnya mampu dan mahir menggunakan IT dalam pembuatan perangkat pembelajaran,apalagi menggunakan IT dalam proses pembelajaran sangat kurang.Hal ini terbukti ketika kepala sekolah melakukan pemantauan terhadap perangkat pembelajaran,ketika Kepala Sekolah melaksanakan Supervisi Akademik dari 6 orang guru kelas, hanya 3 orang guru yang dapat menyelesaikan perangkatnya sendiri dengan menggunakan IT, sedangkan 3 orang guru kelas dan guru olah raga masih minta bantuan kepada operator dan orang lain. Apalagi kemampuan menggunakan IT dalam proses pembelajaran.

Untuk mengatasi hal tersebut, Kepala Sekolah Dasar Negeri 02 Kubang perlu mencari solusi supaya guru mampu mengoperasikan IT dan memanfaatkan IT sebagai media pembelajaran.Salah satu cara untuk mengatasi hal tersebut adalah memberikan pelatihan kepada guru untuk mengoperasikan laptop, agar guru mampu menggunakan laptop atau komputer dalam membuat perangkat pembelajarannya. Pelatihan yang dapat diberikan kepada guru yaitu melalui In House Training (IHT).In House Training adalah sebuah bentuk pelatihan dimana materi pelatihan,waktu serta tempat pelatihan ditentukan sesuai dengan yang diminta dan dibutuhkan oleh peserta. Banyak lagi istilah yang digunakan In House Training. Ayuningtyas (2017) menyatakan In House Training (IHT) adalah program pelatihan yang diselenggarakan di sekolah atau tempat lain dengan menggunakan peralatan dan materi yang cocok dengan permasalahan yang dihadapi dengan tujuan untuk mengembangkan kompetensi berupa keterampilan, pengetahuan, prilaku.

Dengan adanya program yang dilakukan kepala sekolah dalam membimbing guru menggunakan IT akan membantu guru dalam peningkatan kompetensi pada era globalisasi yang merupakan salah satu kompetensi guru yang perlu ditingkatkan yaitu kompetensi profesional.Suhadi(2007) mengemukakan bahwa"Perangkat pembelajaran adalah sejumlah bahan, alat, media, petunjuk dan pedoman yang akan digunakan dalam proses pembelajaran." Dari uraian tersebut dapatlah dikemukakan bahwa perangkat pembelajaran adalah sekumpulan media atau sarana yang digunakan guru dalam menghadapi pembelajaran di kelas,

Berdasarkan penjelasan diatas kepala sekolah dasar negeri 02 Kubang perlu melakukan Penelitian Tindakan Sekolah (PTS) yang berjudul "Peningkatan Kemampuan Guru Memanfaatkan IT dalam Pembuatan Perangkat Pembelajaran melalui In House Training ( IHT ) di SD Negeri 02 Kubang."

Berdasarkan latarbelakang permasalahan di atas, maka identifikasi permasalahan penelitian ini adalah sebagai berikut:

1. Guru belum mampu dan mahir menggunakan IT.

2. Guru masih minta bantuan dalam membuat perangkat pembelajaran

3. Guru belum memanfaatkan IT dalam Pembelajaran.

Penelitian ini dibatasi hanya membahas tentang Peningkatan Kemampuan Guru Memanfaatkan IT dalam Pembuatan Perangkat Pembelajaran di SD Negeri 02 Kubang. Berdasarkan latar belakang di atas dapat dirumuskan masalah penelitian yaitu: Apakah melalui In House Training (IHT) dapat meningkatkan kemampuan guru memanfaatkan IT dalam pembuatan Perangkat Pembelajaran di SD Negeri 02 Kubang?" 
Penelitian ini bertujuan untuk: meningkatkan kemampuan guru memanfaatkan IT dalam pembuatan Perangkat Pembelajaran di SD Negeri 02 Kubang. Manfaat penelitian ini adalah: Siswa dapat belajar lebih efektif serta meningkatkan hasil belajar. Guru mampu menggunakan IT dalam membuat perangkat pembelajaran. Bagi Peneliti (Kepala Sekolah) untuk menambah pengetahuan dan pengalaman peneliti dalam menerapkan pengetahuan serta mengelola sekolah, sehingga mampu memecahkan masalah-masalah yang dihadapi di dunia pendidikan. Diharapkan dengan adanya hasil darimpenelitian ini dapat menjadi masukan yang berharga bagi pihak sekolah, khususnya dalam penggunaan IT di sekolah.

\section{METODE PENELITIAN}

Sesuai dengan masalah dan tujuan yang hendak dicapai, jenis penelitian yang digunakan adalah Penelitian Tindakan Sekolah (PTS). Mulyasa mengatakan bahwa Penelitian Tindakan Sekolah merupakan upaya peningkatan kinerja sistim pendidikan dan meningkatkan menejemen sekolah agar menjadi produktif, efektif, dan efisien. Melalui penelitian ini diupayakan guru dapat memanfaatkan media pembelajaran berbasis IT.

Penelitian ini dilaksanakan pada semester II tahun pelajaran 2018/2019selama 4 (empat) bulan mulai Januari s.d. April 2019. Penelitian Tindakan Sekolah ini dilaksanakan di Sekolah Dasar Negeri 02 Kubang, Kecamatan Guguak, Kabupaten Lima Puluh Kota. Pemilihan tempat penelitian ini didasari oleh beberapa hal antara lain:

1. Sekolah Dasar Negeri 02 Kubang merupakan sekolah yang peneliti pimpin dalam tugas sebagai kepala sekolah.

2. Guru Sekolah Dasar Negeri 02 Kubang belum mampu menggunakan media pembelajaran berbasis IT dalam membuat perangkat pembelajaran.

Subyek Penelitian Tindakan Sekolah ini adalah guru SDN 02 Kubangsebanyak 8 orang. Perempuan 7 orang dan laki-laki 1 orang.

Sumber data penelitian ini adalah guru sebagai subyek penelitian dan kepala sekolah sebagai peneliti atau nara sumber.Adapun hal-hal yang menjadi data dalam penelitian ini adalah:

1. Hasil tes kemampuan guru menggunakan $I T$

2. Tindakan kepala sekolah dalam kegiatan In House Training (IHT)

3. Aktivitas guru dalam kegiatan IHT.

4. Hasil veer teaching gurumemanfaatkan media pembelajaran berbasis IT

5. Kesan guru terhadap pemanfaatan IT dalam pembelajaran melalui kegiatan IHT.

Apabila sumber data berasal dari kepala sekolah maka aspek yang diamati adalah tindakan kepala sekolah dalam pelaksanaan kegiatan IHT. Selanjutnya jika sumber data dari guru, berasal dari kegiatan guru dalam kegiatan IHT. Hal yang diamati adalah sikap prilaku guru dalam kegiatan, dan kesan guruterhadap penggunaan IT dalam pembuatan Perangkat Pembelajaran.

Desain Penelitian yang digunakan adalah model Arikunto (2010) yang terdiri dari empat komponen yaitu, (1) Perencanaan (planning), (2). tindakan (action), (3) pengamatan (observing), (4) refleksi (reflecting). Keempat komponen ini membentuk kegiatan yang disebut siklus. Diagram alur desain penelitian ini dapat dilihat pada bagan di bawah ini.Bagan di atas dapat dijelaskan 
sesuai dengan kegiatan siklus. Kegiatan siklus lebih rinci diuraikan di bawah ini.

Berdasarkan permasalahan yang ditemui pada guru di SDN 02 Kubang ketika orientasi dan observasi dalam menggunakan IT untuk membuat perangkat pembelajaran, ternyata dari jumlah guru 9 orang terdapat 4 orang (44,4\%), yang sudah mampu IT sedangkan 5 orang $(55,6 \%)$ kurang mampu IT. Terkait dengan hal tersebut jumlah guru yang mampu IT 4 orang, hanya 2 orang, (50 \%) yang memanfaatkan IT dalam pembuatan perangkat pembelajaran. Oleh sebab itu, dilaksanakan tindakan dengan suatu kegiatan In House Training (IHT). Tindakan ini diharapkan dapat meningkatkan kemampuan guru menggunakan IT serta dapat memanfaatkan IT dalam persiapan pembelajaran. Kegiatan PTS mempunyai 4 tahap yaitu tahap persiapan (perencanaan), pelaksanaan, observasi, dan refleksi

Dalam kegiatan perencanaan yang dilakukan adalah:

a. Menyusun Kegiatan Panduan IHT

b. Melaksanakan sosialisasi sehubungan dengan pelaksanaan kegiatan IHT.

c. Melaksanaan rapat pembentukan panitia pelaksanaan $I H T$

d. Mempersiapkan materi pemanfaatan IT dalam penyusunan perangkat pembelajaran .

e. Mempersiapkan ruangan dan perlengkapan yang dibutuhkan dalam kegiatan IHT.

f. Mempersiapkan instrumen penelitian berupa Lembar observasi untuk kegiatan Kepala Sekolah dan kegiatan Guru.

Kegiatan IHT dititikberatkan pada pemanfaatan IT dalam pembuatan perangkat pembelajaran. Tindakan berlangsung timbal balik peneliti (pelaksana) dengan peserta, peserta sesama peserta serta peserta dengan peneliti. Pelaksanaan tindakan secara umum berdasarkan langkah-langkah kegiatan IHT yaitu:

Pelaksanaansiklus I, pertemuan pertama dimulai dengan pemberian apersepsi pentingnya pemanfaatan IT dalam penyusunan perangkat pembelajaran,

Kegiatan inti pelatihan sebagai berikut:

a. Peserta pelatihan memperoleh informasi seputar pemanfaatan teknologi dalam penyusunan perangkat pembelajaran.

b. Peneliti mendemontrasikan cara yang baik mengoperasikan IT (leptop) serta memanfatkan ITdalam pembuatan perangkat pembelajaran.

c. Peserta diminta untuk mempraktikkan cara yang baik mengoperasikan IT (leptop) serta menggunakanya dalam pembuatan perangkat pembelajaran berbasis $I T$.

d. Peserta menunjukkan kemampuan memanfaatkan IT dalam membuatperangkat pembelajaran menurut cara yang telah dipelajarinya dibimbing oleh pelatih.

e. Pelatih membimbing guru (peserta) dengan penuh tanggung jawab dan ikhlas.

f. Peserta belajar bersama teman sejawat.

Tindakan siklus I pertemuan kedua dengan ketiga tidak jauh berbeda dengan pertemuan pertama. Intinya, peserta pelatih mendapatkan bimbingan untuk mempelajari menggunakan $I T$ dalam membuat perangkat pembelajaran. Tindakan siklus II dilaksanakan berdasarkan langkah-langkah kegiatan pada siklus 1. Hanya saja pada siklus II pelatihan difokuskan pada indikator yang belum tercapai pada siklus I. 
Pengamatan dilaksanakan setiap kegiatan. Peneliti memantau setiap kegiatan yang terjadi dengan menggunakan lembar observasi, baik kegiatan yang dilaksanakan oleh kepala sekolah sebagai peneliti maupun kegiatan guru sebagai subyek penelitian. Dalam pengamatan instrumen lembar observasi diisi oleh peneliti/kepala sekolah sebagai penyelenggara kegiatan $I H T$.

Kegiatan yang dilaksanakan pada refleksi adalah (1) Merenung dan mencermatikembali tahap-tahap kegiatanIHT yangtelah dilaksanakan, (2) Mencermati hasil instrument lembar observasi peserta maupun pelaksana IHT (3) Mencatat hal-hal yang dirasaperlu, terutama indikator yang belum berhasil (4) menganalisis hasil yang telah dicapai dan yang belum. (5) Membuat rekomendasi untuk siklus ke -2 .

Semua informasi data yang diperoleh dari hasil pengamatan tindakan (observing) dianalisis pada tahap ini.Data yang didapat dianalisis untuk melihat kemampuan guru memanfaatkan IT dalam membuat perangkat pembelajaran. Hasil yang tajam dan terpercaya akan memberikan masukan dan sebagai bahan pertimbangan dalam melakukan tindakan untuk siklus berikutnya.

Penelitian ini merupakan Penelitian Tindakan Sekolah guna meningkatkan kemampuan guru menggunakan IT media dalam pembuatan perangkatan pembelajaran. Peneliti sebagai instrument utama. Instrumen lain yang digunakan adalah lembar observasi peneliti dan guru. Terakhir, peneliti mengajukan quesioner kepada guru peserta penelitian guna mengetahui pendapat peserta tentang pelaksanaan In House Training dalam meningkatkan kemampuan guru dalam pemanfaatan IT menyusun perangkat pembelajaran.

Penelitian Tindakan Sekolah adalah jenis penelitian kualitatif. Sumber data utama dalam penelitian kualitatif adalah kata-kata, tindakan, dan dokumen (lembar observasi kegiatan kepala sekolah dan peserta dalam memanfaatkan

Dalam pelaksanaan Penelitian Tindakan Sekolah data yang dikumpulkan yaitu data kualitatif. Data kualitatif berupa hasil instrument monev (Lembar Observasi), dan agket.

1. Lembar Observasi

Selanjutnya, peneliti mengolah data berdasarkan temuan pada lembar observasi/monev peneliti dan peserta dengan menggunakan persentase. Perolehan analisa data kemudian dikelompokkan berdasarkan empat kategori kemampuan guru, yaitu perolehan nilai anatara $90 \leq \mathrm{A} \leq 100$ adalah Amat Baik (AB), $75 \leq \mathrm{B}<90$ adalah Baik (B), $60 \leq \mathrm{C}<74$ adalah Cukup (C), dan $<60$ adalah Kurang (K).

2. Pertanyaan/angket

Data hasil analisis yang telah selesai diinterpretasikan selanjutnya dilaporkan dalam bentuk tulisan yang telah ditentukan sesuai dengan kaidah penulisan Penelitian Tindakan Sekolah.

Tindakan Penelitian Sekolah ini dikatakan berhasil apabila guru mampu menyusun perangkat dengan minimal Baik dan nilai perolehan kemampuan guru minimal $80 \%$ mencapai nilai Baik. 


\section{HASIL PENELITIAN DAN PEMBAHASAN}

\section{Hasil Penelitian}

\section{Siklus I}

Penelitian Tindakan Sekolah ini dilaksanakan di SDN 02 Kubang pada Semester 2 tahun pelajaran 2018/2019. Penelitian ini diikuti oleh 9 orang guru sebagai subyek penelitian. In House Training adalah suatu strategi yang peneliti gunakan untuk meningkatkan kemampuan guru dalam menggunakan IT untuk menyusun perangkat pembelajarn. Penelitian ini dilatarbelakangi oleh masih banyak guru yang belum memanfaatkan IT dalam persiapan pembelajaran maupun penyusunan perangkat pembelajaran. Walaupun guru sudah mampu mengoperasikan komputer atau laptop, namun mereka lebih cendrung mengharapkan bantuan pengetikan maupun pengolahan nilai dengan bantuan orang lain, anak atau operator sekolah. Jadi dengan kegiatan In House Training ini diharapkan dapat membantu guru dalam penyusunan perangkat pembelajaran termasuk pengolahan nilai.

Pada tahap perencanaan ini, peneliti melakukan pendekatan dan sosialisasi pada guru agar mereka mau meluangkan waktu dalam mengikuti pelatihan. Pelatihan dilaksanakan pada siang hari setelah peserta didik pulang, artinya pelaksanaan PTS tidak menganggu terhadap Proses Pembelajaran di sekolah. Selain menginformasikan kegiatan kepada guru, peneliti juga mempersiapkan instrumen yang digunakan dalam penelitian. Instrumen yang digunakan pada siklus I ini adalah lembar observasi kegiatan peneliti/Kepala Sekolah dan lembar observasi kegiatan guru.

1. Pertemuan 1

Pada pertemuan 1 ini peneliti memberikan paparan tentang manfaat IT terhadap kemudahan kerja dan tugas-tugas guru. Dengan pemanfaatan IT guru lebih terbantu dalam penyusunan perangkat pembelajaran. Kalau guru sudah mampu mengoperasikan IT sendiri, maka guru dapat menghemat waktu, tenaga, dan uang dalam mempersiapkan perangkat.

Pada pertemuan 1 ini, peneliti memberikan pelatihan bagaimana mengoperasikan komputer atau laptop dengan microsoft word. Aplikasi ini sangat dibutuhkan guru dalam menyusun perangkat pembelajaran.

2. Pertemuan 2

Pertemuan 2, dilaksanakan pelatihan terhadap guru dalam pengetikan dan penyusunan perangkat. Guru dibimbing mulai dari pengetikan identitas RPP sampai selesai. Peneliti juga membimbing guru dalam menggunakan font, membentuk huruf tebal, membuat tabel, memasukkan gambar ke file dan menyalin dokumen dari dokumen lain dan menempelkan dokumen tersebut ke dokumen yang sedang dikerjakan (copy paste).

3. Pertemuan 3

Pada pertemuan ke 3, peneliti, meminta guru menyelesaikan satu RPP yang akan digunakan untuk pengajaran. Pada pertemuan ini peneliti dibantu oleh guru-guru yang sudah mahir dalam penggunaan IT. Guruguru tersebut membimbing teman-teman guru dalam menyelesaikan pekerjaannya. Bimbingan diberikan dalam bentuk arahan dan cara menggunakan perangkat. 
1. Lembar Observasi Kepala Sekolah

Dari pengamatan terhadap kegiatan kepala sekolah dalam melaksanakan IHT untuk meningkatkan kemampuan guru dalam memanfaatkan IT dalam penyusunan perangkat pembelajaran adalah dengan menggunakan lembar observasi. Lembar observasi diisi oleh kepala sekolah berupa ceklis.

Dari temuan penelitian dapat dijelaskan bahwa kepala sekolah sebaai peneliti telah mempersiapkan segaa sesuatunya dengan baik. Dari patauan lebar observasi, terlihat dari pertemuan 1 sampai pertemuan 3 pada siklus I, peneliti memperoleh nilai $75 \%$ dengan kategori Baik. Dari temuan ini dapat disimpulka bahwa kepala sekolah bena-benar mempersipakan diri dalam membimbing guru dalam pemanfatan IT.

2. Lembar Observasi Guru

Dari pantauan kegiatan guru sebagai subyek penelitian adalah sebagai berikut:

a. Perolehan berdasarkan indikator instrumen

Temuan pada siklus I untuk kegiatan guru dapat dijelaskan bahwa ratarata nilai perolehan adalah 61,90 dengan kategori C. Dari temuan ini dapat dijelaskan bahwa guru belum begitu serius dalam mempelajari materi yang disajikan pada pelatihan. Sehingga dari lembar observasi terlihat perolehan bahwa semua indikator pada lembar observasi diperoleh nilai dengan kategori $\mathrm{C}$.

b. Perolehan berdasarkan kemampuan individu guru

Perolehan dari lembar observasi guru sebagai peserta pelatihan terlihat masih rendah. Rata-rata perolehan nilai adalah 69,7 dengan kategori $\mathrm{C}$.

Dari temuan siklus I, maka peneliti beserta guru merenungkan perolehan penelitian. Dari temuan penelitian dapat disimpulkan bahwa guru belum begitu serius mengikuti pelatihan. Oleh sebab itu peneliti dan guru bersepakat untuk melaksanakan penelitian pada siklus II dengan lebih serius dan fokus terhadap materi yang diberikan.

\section{Siklus II}

Perencanaan pada siklus II dilaksanakan hampir sama dengan perencanaan siklus I. Kegiatan yang dilakukan antara lain penentuan jadwal pelaksanaan, penyusunan materi pelatihan dan penyiapan instrumen penelitian berupa lembar observasi kepala sekolah, guru dan daftar pertanyaan untuk quesioner setelah penelitian siklus II selesai.

a. Pertemuan 1

Pada pertemuan 1, peneliti menjelaskan penggunaan microsoft excel dalam pengolahan nilai. Peneliti menayangkan bagaimana memanfaatkan program ini dalam mengerjakan pekerjaan yang berhubungan dengan bilangan dan angka-angka. Kemudian peneliti memperagakan bagaimana cara mengoperasikan program excel dengan nilai siswa.

b. Pertemuan 2

Peserta mempraktekkan penghitungan nilai dengan program excel. Pada kesempatan ini guru yang sudah mahir membantu temannya dalam mengoperasikan program. Sehingga terciptalah kerjasama teman sejawat yang baik. Pada kesempatan tersebut dapat dilihat keseriusan para peserta dalam menyelesaikan tugas-tugas yang diberikan kepala sekolah dalam rangka pelatihan dengan IHT. 


\section{c. Pertemuan 3}

Para peserta pada pertemuan 3 ini, diminta mengumpulkan dan saling mencek hasil pekerjaan mereka. Disini peneliti hanya mengamati saja. Namun pertanyaan yang diajukan peserta ketika mereka menyelesaikan tugas mereka tetap peneliti layani. Penelitian berjalan dengan baik dan tertib. Sehingga tercipta kondisi yang kondusif dan menyenangkan selama penelitian.

Pada siklus II ini, peneliti masih menggunakan lembar observasi yang sama dengan siklus I. temuan pada siklus II ini adalah sebagai berikut:

a. Lembar Observasi Kepala Sekolah

Berdasarkan temuan pada siklus II tentang kegiatan kepala sekolah dalam memberikan pelatihan pemanfaatan IT dalam menyusun perangkat pembelajaran adalah Baik. Hal ini terlihat pada rata-rata nilai dari lembar observasi pada pertemuan 1-3 sebesar 88,10 dengan kategori Baik.

b. Lembar Observasi Guru

1) Perolehan berdasarkan indikator instrumen

Dari temuan siklus II dapat dilihat bahwa secara umum guru sudah mampu memanfaatkan IT dalam penyusunan perangkat pembelajaran. Dari perolehan nilai pertemuan 1 adalah 75,79 dengan kategori Baik. Pada pertemuan 2 perolehan meningkat menjadi 76,6 dan pada pertemuan 3 diperoleh nilai 79,76. Dapat disimpulkan partisipasi peserta pada siklus II meningkat dibandingkan dengan partisipasi pada siklus I.

2) Perolehan berdasarkan kemampuan individu guru

Berdasarkan temuan ditinjau dari kemampuan individu guru dalam memanfaatkan IT menyusun perangkat pelajaran melalui pelatihan IHT adalah dengan perolehan rata-rata 82,29 dengan kategori Baik.

Setelah pelaksanaan dan pengamatan pada Siklus II, maka dapat dijelaskan bahwa hasil penelitian sesuai dengan tujuan yang telah ditetatpkan sebelum pelaksanaan penelitian yaitu meningkatkan kemampuan guru dalam memanfaatkan IT menyusun perangkat pembelajaran di SDN 02 Kubang dengan menggunakan pelatihan yang disebut dengan In House Training (IHT). berdasarkan kriteria keberhasilan penelitian bahwa minimal $80 \%$ guru memperoleh nilai minimal Baik. Dari temuan diperoleh data bahwa semua guru peserta IHT sebanyak 8 orang memperoleh nilai Baik. Jadi penelitian dihentikan sampai siklus II.

quesioner/angket adalah berupa pertanyaan yang dijawab oleh peserta pelatihan. Kegiatan ini dilaksanakan setelah kegiatan siklus II selesai. Jumlah pertanyaan adalah 5 buah. Pertanyaan tentang kepuasan dan peningkatan kemampuan guru setelah penelitian dilaksanakan. Dari delapan orang guru peserta pelatihan dalam PTS ini, semuanya menyatakan bahwa: kegiatan IHT dapat membantu mengatasi masalah dalam pembelajaran, mereka sudah mampu mengoperasikan komputer atau laptop dengan menggunakan program microsoft office word dan excel. Mereka menyatakan kepuasan dengan pelatihan IHT mereka terbantu menyusun perangkat pembelajaran dengan baik dan cepat. 


\section{Pembahasan}

In House Training (IHT) adalah salah satu pelatihan yang dapat dilakukan oleh kepala sekolah untuk meningkatkan kemampuan/kompetensi guru. Pelaksanaan IHT adalah sangat cocok karena waktu dan jadwal pelatihan dapat disepakati oleh guru dan kepala sekolah. Disamping itu biaya yang dibutuhkan juga relatif murah. Kepala sekolah tidak harus menyediakan dana untuk nara sumber karna nara sumber bisa diambil/dipilih dari guru maupun kepala sekolah itu sendiri.

Berdasarkan temuan dari penerapan IHT di SDN 02 Kubang dalam rangka meningkatkan kemampuan guru memanfaatkan IT dalam penyususnan perangkat pembelajaran dapat diperoleh hasil yang memuaskan. Temuan penelitian tindakan sekolah tersebut adalah sebagai berikut:

1. Lembar Observasi Kepala Sekolah

Berdasarkan temuan penelitian tindakan sekolah ini, dapat dijelaskan bahwa untuk kepala sekolah juga terjadi peningkatan. Dari pengamatan siklus I dan siklus II maka terjadi peningkatan secara rata-rata kemampuan kepala sekolah dalam melaksanakan IHT di SDN 02 Kubang sebesar 13,10 poin.

2. Lembar Observasi Guru

Peningkatan kemampuan guru ditinjau dari indikator yang ada pada lembar observasi dapat diperoleh dari siklus I ke siklus II sebesar 15,48 poin.

\section{Peningkatan kemampuan guru}

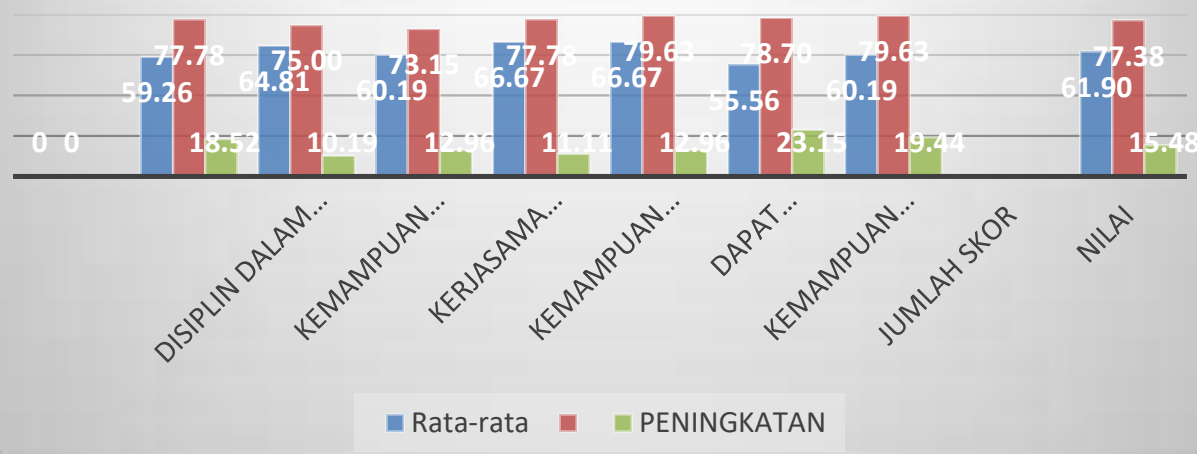

Grafik 1: Peningkatan kemampuan guru ditinjau dari indikator

3. Kemampuan individu guru

Kemudian, peningkatan kemampuan individu guru dari siklus I ke siklus II adalah 13 poin. Peningkatan tertinggi terjadi pada guru dengan kode IS yaiut sebesar 19 poin. Peningkatan terendah adalah 5 poin 


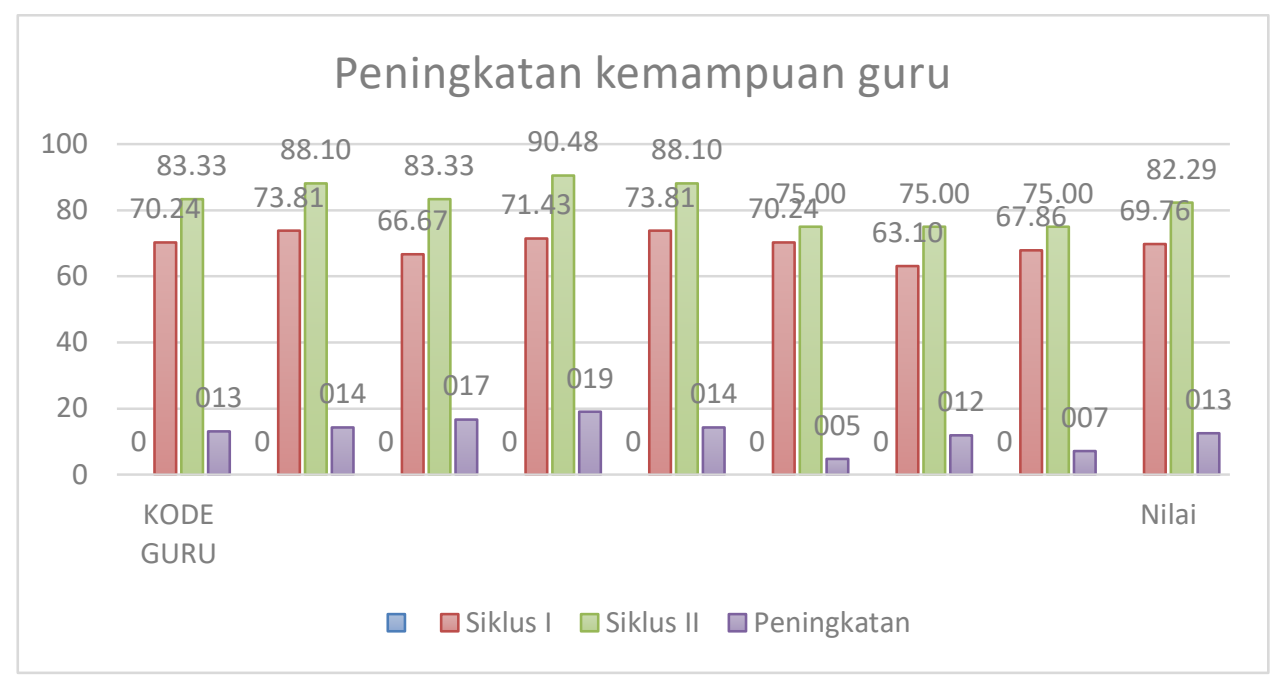

Grafik 2: Peningkatan kemampuan individu guru

\section{KESIMPULAN DAN SARAN}

Berdasarkan temuan dari penelitian tindakan sekolah ini maka dapat disimpulkan bahwa:

a. In House Training dapat meningkatkan kemampuan guru dalam menyusun perangkat pembelajaran di SDN 02 Kubang pada semester 2 tahun pelajarn 2018/2019. hal ini dibuktikan adanya peningkatan perolehan nilai kemampuan guru dari siklus I ke siklus II sebesar 15,48 poin pada indikator lembar observasi guru dan 5 poin pada peningkatan kemempuan guru.

b. Dari quesioner yang diberikan kepada guru, IHT juga berdampak positif terhadap pembelajaran guru dikelas.

Saran dalam penelitian adalah sebagai berikut:

a. Kepala sekolah hendaknya selalu membuat inovasi dan kreatifitas dalam rangka peningkatan kompetensi diri sendiri dan kompetensi guru di sekolah yang dipimpin.

b. Guru sebaiknya selalu melakukan pengayaan diri agar bisa bersaing dengan dengan guru lain dalam era globalisasi. Sehingga guru tidak ketinggalan dalam IT.

c. Penelitian ini baru meneliti kemampuan guru dalam pemanfaatan IT menyusun perangkat pembelajaran, maka untuk peneliti selanjutnya dapat pula mengembangkan IHT dengan penggunaan IT pada media pembelajaran dan karya inovatif lainnya.

\section{DAFTAR PUSTAKA}

Abdul Kadir dan Terra Ch. Triwahyuni. 2013. Pengantar Teknologi Informasi Edisi Revisi. Yogyakarta: Andi

Arikunto, S. 2010. Prosedur Penelitian (Suatu Pendekatan Praktik), Jakarta: Rineka Cipta 
Ayuningtyas, A. E., Slameto \& Dwikurnaningsih, Y. 2017. Evaluasi Program Pelatihan In House Training (IHT) di Sekolah Dasar Swasta. Jurnal Manajemen Pendidikan. .

Khaerudin, Mahfud Junaedi dkk. 2007. Kurikulum Tingkat Satuan Pendidikan, Konsep dan Implementasi di Madrasah. Yogyakarta: Nusa Aksara.

Peraturan Menteri Pendidikan Nasional nomor 13 tahun 2007 tentang standar Kepala Sekolah/Madrasah

Peraturan Menteri Pendidikan dan Kebudayaan nomor 15 Tahun 2018 tentang Pemenuhan Beban Kerja Guru,Kepala Sekolah,dan Pengawas

Permendikbud No. 65 Tahun 2013 tentang Standar Proses Pendidikan Dasar dan Menengah

Sanjaya, Wina. 2010. Strategi Pembelajaran Berorientasi Standar Proses Pendidikan. Jakarta : Prenada Media Group

Suhadi2007 . Petunjuk Perangkat Pembelajaran. Surakarta: Universitas Muhammadiyah 